\title{
Management of Cholesteatoma by Intact Canal Wall Mastoidectomy
}

\author{
V Rajarajan* \\ Department of ENT, The Tamil Nadu Dr. MGR Medical University, India
}

Submission: April 25, 2017; Published: May 24, 2017

*Corresponding author: V Rajarajan, Department of ENT, The Tamil Nadu Dr. MGR Medical University, India, Tel: 9443398098;

Email: drvrrajan@gmail.com

\begin{abstract}
Surgeries for cholesteatoma have been refined more towards maintaining an intact canal wall whenever possible in limited disease. The surgery of choice for such cases has also been a controversy over time, weighing the advantages over disadvantages. This case series describes the selection methodology for an intact canal wall (ICW) mastoidectomy and also the operative results for the various ossicular statuses of the patients during a six year study period
\end{abstract}

Keywords: Mastoidecomy; Closed cavity; Intact canal; Canal wall-up

\section{Introduction}

Intact canal wall mastoidectomy is a closed cavity mastoidectomy with the preserved acoustic advantage of middle ear space as well as physical advantage for hearing aid application. These factors have made the preservation of posterior canal wall or the canal wall up procedure advantageous over a canal wall down mastoidectomy, in patients with limited attic cholesteatoma. Unlike the canal wall down mastoidectomy, this method preserves much of the anatomy and provides less of cosmetic defect of a wide external auditory canal. Moreover, the intact canal wall technique has similar results in disease clearance when patient selection is appropriate and posterior canal wall is reconstructed to prevent retraction pockets.

\section{Indications of ICW Technique}

The indications for intact canal wall mastoidectomy has been elaborated in cases of,

a) Cholesteatoma confined to attic, middle ear with extension into antrum without any intracranial complications and for primary cases of cholesteatoma.

b) Contraindicated in recidivism cases.

\section{Advantages of ICW Technique}

In this procedure posterior wall of external auditory canal preserved, by removing cholesteatoma from its extensions (mastoid air cells) towards the site of origin i.e. attic or post sup. part of mesotympanum as into manner. Thereby maintaining normal anatomy and avoiding cavity problems associated with canal wall down mastoidectomy. But the procedure requires great amount of skill on the part of surgeon by not leaving behind any residues especially in crevices in mesotympanum. This procedure also provides adequate middle ear space unlike canal wall down procedure, where the tympanic ring is drilled out and the lateral wall of middle ear is medialized to the level of facial ridge.

\section{Selection of Candidates Based on Pneumatization of Mastoid}

Limited cholesteatoma in a well pneumatized mastoid can be very well taken up for an intact canal wall mastoidectomy after confirming an adequately functioning eustation tube. Such patients will have the additional advantage of easy mucosalization from the remaining normal mastoid cell mucosa, regaining ventilation mechanics which was earlier distorted by cholesteatoma sac and surrounding inflammation and faster healing following reconstruction of posterior canal wall. The need for a cumbersome and a long follow-up following canal wall down procedure for the sake of aural toileting and wax removal, for a very large post-operative cavity such as that of the pneumatized mastoid, in a canal wall down procedure is avoided.

Such well pneumatized mastoids must also be taken up for an extensive intratympanic workout to eradicate the disease in the facial recess with sacrifice of chorda tympani if necessary. Use of angled endoscopes for works along the sinus tympani and the anterior attic has provided an around-the-edge view that a 
microscope could not possibly provide, not without much effort and quiet possibly cannot at all. It is worth knowing that selecting well pneumatized mastoids for a canal wall up procedure must include a second- stage ossicular reconstruction procedure if extensive intra-tympanic work has been done. This not only improves the hearing reconstruction result but also provides a second-look to remove nests of keratin pearls easily in areas of recurrence as the inflammation has already settled down and the mucosa is healed for any manipulation.

Sclerosed mastoid are preferably taken for a canal wall down procedure in cases with Eustachian tube dysfunction to prevent retraction pockets and hence, recurrence. If the patient is taken up for an intact canal procedure, it is mandatory to provide a cartilaginous posterior canal wall reconstruction with mastoid cavity obliteration. This well prevents the cavity problems caused by a high facial ridge and the mucosa lined sclerosed mastoid cavity forming a reservoir, accounting for the long term post-operative aural discharge and problems with fitting a hearing.

\section{Contraindications For ICW Mastoidectomy}

a) Revision or residual cholesteatoma

b) Intra cranial complications.

c) Unreconstructable posterior canal wall defect.

d) Poor compliance of patients.

e) Unresectable matrix involving the labyrinth, facial nerve, dura and sinus tympani.

\section{Case Series}

The study involving 93 atticoantral cases who underwent intact canal wall mastoidectomy following audiological and radiological evaluation, with a 6 yr follow-up and assessed the hearing status using pure tone audiometry. Intact canal wall mastoidectomy was done by postaural incision, with elevation of periosteal flap and mastoidectomy done exposing the cholesteatoma sac and drilling extended around to expose the sac completely. Then posterior atticotomy was done to expose the extension in the attic and to visualize the head of malleus and body of incus, which if present were removed to clear the attic of cholesteatoma material. The cholesteatoma sac mobilised from the mastoid air cells taking care not to leave behind any residue towards the mesotympanum and removed completely. In cases with facial recess involvement, posterior tympanotomy was done and with hypotympanic extension of the cholesteatoma sac, and if needed, extended facial recess approach by sacrificing the chorda tympani nerve, was done for adequate exposure.

Removal of disease in the attic requires further enlargement of anterior attic by thinning the tegmen tympani till anterior malleolar ligament becomes visible. In contrast to sinus cholesteatoma, tensa retraction cholesteatoma can extend under anterior malleolar fold towards the attic, therefore necessitating removal of the malleus head for complete eradication of the disease. Eroded ossciles are removed and the remnant incus/ malleus may be preserved for ossicular reconstruction. Then, a type 3 tympanoplasty was done for all cases. If the head of stapes is lower than the, annulus then conchal cartilage graft was placed over it to make contact with tympanic membrane or fascia graft [1-3].

The defect in the lateral attic wall and posterosuperior region reconstructed with semilunar shaped conchal cartilage with (preserved perichondrium) convex side facing external auditory canal and supported behind with gelfoam for stabilization. The mastoid air cells smoothened with diamond burr after complete removal. The temporalis fascia used to reconstruct the tympanic membrane. The tympanomeatal flap repositioned and gel foam kept over it. Mupirocin ointment was used to fill the external auditory canal. Wound closed in layers after complete haemostasis. All cases were explained about the procedure and its advantage and the need for revision and if found necessary, may be converted into a modified radical mastoidectomy and consent was obtained for the same. Post op antibiotics were continued for 2 weeks period with 3rd generation cephalosporins. Sutures were removed on 7 th post operative day [4].

Results

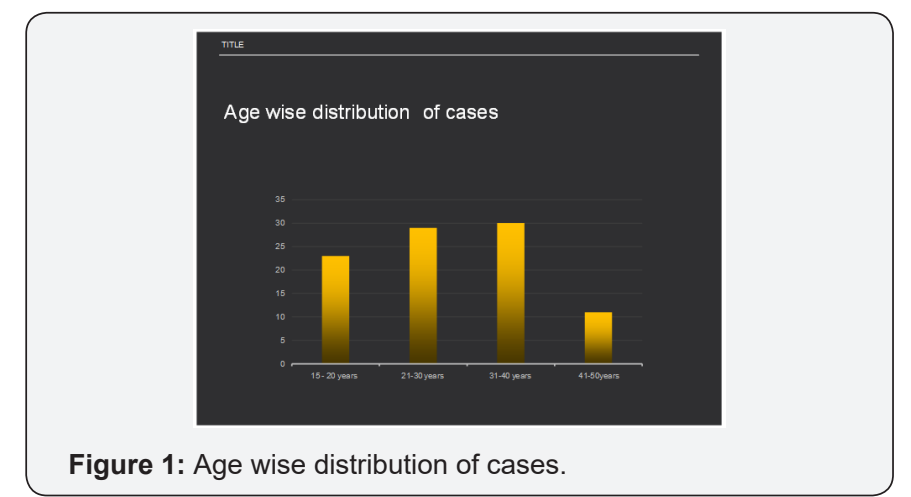

Table 1: Ossicular Status.

\begin{tabular}{|c|c|c|c|}
\hline $\begin{array}{c}\text { NO.OF } \\
\text { PATIENTS } \\
\text { (OSSICULAR } \\
\text { STATUS } \\
\text { + PRESENT } \\
\text { - ABSENT) }\end{array}$ & $\begin{array}{c}\text { MALLEUS } \\
\text { PARTIALLY }\end{array}$ & $\begin{array}{c}\text { INCUS LONG } \\
\text { PROCESS } \\
\text { ABSENT }\end{array}$ & $\begin{array}{c}\text { STAPES } \\
\text {-SUPRA } \\
\text { STRUCTURE }\end{array}$ \\
\hline 62 & + & - & + \\
\hline 28 & - & - & + \\
\hline 3 & - & - & - \\
\hline
\end{tabular}

The results of the study are shown in the tables below, (Figure 1) (Table 1). Ossicular reconstruction was done using autologous incus \& conchal cartilage. In 47 cases where stapes suprastructure was intact, incus was reshaped and kept over it. In 43 cases conchal cartilage was reshaped and placed over the stapes suprastructure. In 3 cases where stapes suprastructure was absent autologous incus was reshaped and kept over mobile footplate (Table 2). In most of cases the long process of incus 
was absent. If the stapes is absent the cartilage was kept over the foot plate to make contact with tympanic membrane. Stapes was absent in 3 cases and long process of incus was absent in 90 cases [5-7]. Handle of malleus was preserved whenever possible to maintain the tensile strength of tympanic membrane. The healing time was about 3 weeks for most of the cases and 29 patients had a healing time of more than 3 weeks for the ear to become dry. Audiological assessment done after 6 months revealed an improved hearing status in most of the patients (Figures 2 \& 3).

Table 2: Ossicular reconstruction status

\begin{tabular}{|c|c|c|}
\hline Ossicular reconstruction status & $\begin{array}{c}\text { No. of } \\
\text { patients }\end{array}$ & $\begin{array}{c}\text { Percentage of } \\
\text { cases }\end{array}$ \\
\hline $\begin{array}{c}\text { Auto Ossicle Over Stapes Supra } \\
\text { Structure }\end{array}$ & 47 & $50 \%$ \\
\hline $\begin{array}{c}\text { Conchal Cartilage Over Stapes } \\
\text { Suprastructure }\end{array}$ & 43 & $45 \%$ \\
\hline $\begin{array}{c}\text { Auto Ossicle Over Stapes Mobile } \\
\text { Footplate }\end{array}$ & 3 & $5 \%$ \\
\hline
\end{tabular}
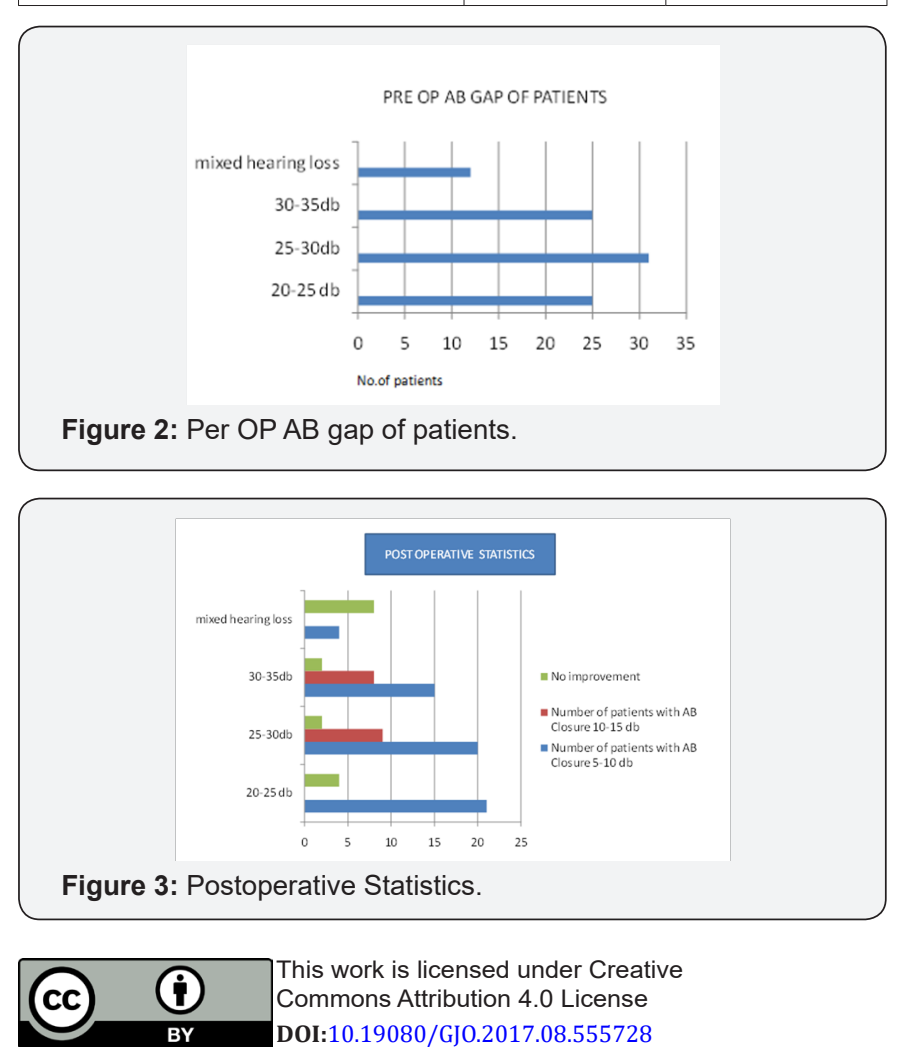

\section{Complications}

Cartilage migration was seen in 8 cases towards the mesotympanum. Since it did not cause any major audiological effects or retraction pockets, it was left alone in those cases. Persistent discharge was seen in 3 cases post operatively for more than 4 weeks and these cases were revised to modified radical mastoidectomy on the 5 th week. In these cases small residual disease was seen in epitympanic recesses which were cleared. Two cases had central perforation during the followup and tympanic membrane reconstruction was done. The mean follow up was 6 months to 3 years. The success rate of the surgery was $96.7 \%$ during the follow up.

\section{Conclusion}

Intact canal wall mastoidectomy is a technically challenging surgery aimed at preservation of external auditory canal anatomy. It gives consistent results with complete removal of the disease in carefully selected cases and thereby making healing faster with advantage of avoiding cavity problems associated with canal wall down mastoidectomy.

\section{Reference}

1. Wilson KF, London NR, Shelton C (2013) Tympanoplasty with intact canal wall mastoidectomy for cholesteatoma: long-term hearing outcomes. Laryngoscope 123(12): 3168-3171.

2. Vrabec JT, Champion SW, Johnson RF, Chaljub G (2003) Aeration following intact canal wall mastoidectomy. Ann Otol Rhinol Laryngol 112(9 Pt 1):801-806.

3. James L Sheehy, Mack E Patterson (1967) Intact canal wall tympanoplasty with mastoidectomy:: A review of eight years' experience. Laryngoscope 77(8): 1502-1542.

4. MK Schwaber (1979) Intact canal wall mastoidectomy. Otology \& Neurotology 108(7): 977-983.

5. DE Brackmann (1993) Tympanoplasty with mastoidectomy: canal wall up procedures. Otology \& Neurotology 14(4): 380-382.

6. Kyung Wook Heo, Myung Koo Kang, Jae Yeong Park (2014) Alternative to Canal Wall-Down Mastoidectomy for Sclerotic Mastoid Cavities. Ann Otol Rhinol Laryngol 123(1): 47-52.

7. Nishi Sonkhya, Ayal Mittal, Divij Sonkhya (2012) Intact Canal Wall Tympanomastoid Surgery: 10 Years Experience. Indian J Otolaryngol Head Neck Surg 64(4): 319-325.

\section{Your next submission with Juniper Publishers will reach you the below assets}

- Quality Editorial service

- Swift Peer Review

- Reprints availability

- E-prints Service

- Manuscript Podcast for convenient understanding

- Global attainment for your research

- Manuscript accessibility in different formats

( Pdf, E-pub, Full Text, Audio)

- Unceasing customer service

Track the below URL for one-step submission https://juniperpublishers.com/online-submission.php 